\title{
Preparation of Nickel Ferrite/Carbon Nanotubes Composite by Microwave Irradiation Technique for Use as Catalyst in Photo-Fenton Reaction
}

\author{
Caroline Rigo ${ }^{a}$, Eric da Cruz Severo ${ }^{a}$, Marcio Antonio Mazutti ${ }^{a}$, Guilherme Luiz Dotto ${ }^{a}$, Sérgio

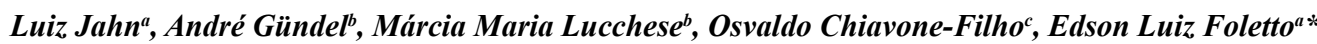 \\ ${ }^{a}$ Department of Chemical Engineering, Universidade Federal de Santa Maria, 97105-900, Santa Maria, \\ RS, Brazil \\ ${ }^{b}$ Universidade Federal do Pampa, 96413-170, Bagé, RS, Brazil \\ ${ }^{c}$ Department of Chemical Engineering, Universidade Federal do Rio Grande do Norte, 59066-800, \\ Natal, RN, Brazil
}

Received: September 15, 2016; Revised: July 4, 2017; Accepted: July 7, 2017

\begin{abstract}
Nickel ferrite/multi-walled carbon nanotubes $\left(\mathrm{NiFe}_{2} \mathrm{O}_{4} / \mathrm{MWCNTs}\right)$ composite has been rapidly synthesized via microwave irradiation technique. The structural properties of the product was investigated by X-ray diffraction (XRD), $\mathrm{N}_{2}$ adsorption/desorption isotherms, thermogravimetric analysis (TGA), Raman spectroscopy and, scanning electron microscopy (SEM). Catalytic behavior of the composite material on the advanced photo-Fenton degradation of Amaranth dye was evaluated. The synthesis conditions employed on the microwave system were: temperature $\left(235^{\circ} \mathrm{C}\right)$, power $(500$ $\mathrm{W})$, pressure $(600 \mathrm{psi})$ and irradiation time $(30 \mathrm{~min})$. Characterization results showed the formation of hybrid material, containing a predominantly microporous structure, with surface area and total pore volume of $54 \mathrm{~m}^{2} \mathrm{~g}^{-1}$ and $0.2249 \mathrm{~cm}^{3} \mathrm{~g}^{-1}$, respectively. The composite exhibited higher catalytic activity compared to the pure $\mathrm{NiFe}_{2} \mathrm{O}_{4}$, reaching $100 \%$ of decolorization at $60 \mathrm{~min}$ of reaction, which can be attributed to a synergism between $\mathrm{NiFe}_{2} \mathrm{O}_{4}$ and MWCNTs. Therefore, $\mathrm{NiFe}_{2} \mathrm{O}_{4} / \mathrm{MWCNTs}$ composite can be used as a promising photo-Fenton catalyst to degrade Amaranth dye from aqueous solutions.
\end{abstract}

Keywords: Multi-walled carbon nanotubes, nickel ferrite, composite, photo-Fenton

\section{Introduction}

Advanced oxidation processes (AOPs) are alternative emerging techniques for the degradation of organic pollutants in wastewater ${ }^{1-6}$. AOPs are divided in a variety of methods, and among them, heterogeneous Fenton reaction is one of the most interests, which to use iron-based solid catalyst, whose major advantage is its easy recovery from the solution by a field magnetic for further reutilization ${ }^{7-9}$. In the presence of a light source, known as photo-Fenton reaction, the pollutant degradation rate substantially increases ${ }^{10,11}$. The photo-Fenton process applies the combination of hydrogen peroxide, iron ions and light irradiation in an acidic aqueous medium $(\mathrm{pH} \leq 3)^{12}$, producing highly oxidative radicals $\left(\mathrm{HO}^{*}\right)^{10}$, leading to degradation of pollutant molecules. Therefore, a simplified mechanism for the heterogeneous photo-Fenton degradation of organic pollutant under light irradiation can be depicted as follows (Equations 1-3):

$$
\begin{aligned}
& \equiv \mathrm{Fe}^{\mathrm{III}}+\mathrm{H}_{2} \mathrm{O}_{2}+\text { light irradiation } \longrightarrow \equiv \mathrm{Fe}^{\mathrm{II}}+\mathrm{HO}_{2}{ }^{+}+\mathrm{H}^{+} \\
& \equiv \mathrm{Fe}^{\mathrm{II}}+\mathrm{H}_{2} \mathrm{O}_{2}+\text { light irradiation } \longrightarrow \equiv \mathrm{Fe}^{\mathrm{III}}+\mathrm{HO}^{\bullet}+\mathrm{H}^{-}
\end{aligned}
$$

Organic pollutant $+\mathrm{HO}^{\bullet} \longrightarrow$ degradation products

$\left(\mathrm{CO}_{2}+\mathrm{H}_{2} \mathrm{O}+\right.$ intermediates $)$

where, $\equiv \mathrm{Fe}^{\mathrm{III}}$ and $\equiv \mathrm{Fe}^{\mathrm{II}}$ corresponds to iron species on the surface of a heterogeneous catalyst.

Recently, coupling of multi-walled carbon nanotubes (MWCNTs) with ferrite have been reported as a potential catalyst for degradation of organic pollutant. This coupling may favor the separation of electron-hole pairs on the catalyst, avoiding their recombination and generating more oxidative radicals $\left(\mathrm{HO}^{*}\right)$, leading to a high catalytic performance ${ }^{13}$.

Several ferrite/carbon nanotubes composites have been used for different applications ${ }^{14-19}$, but very few them have been used for application in OAPs ${ }^{13,20-23}$. Recently, nickel ferrite $\left(\mathrm{NiFe}_{2} \mathrm{O}_{4}\right)$ /carbon nanotubes (MWCNTs) composite has been prepared via a conventional route using teflon-lined stainless autoclave at $180{ }^{\circ} \mathrm{C}$ for $20 \mathrm{~h}$, being applied as photocatalyst for the degradation of phenol under UV irradiation ${ }^{13}$. $\mathrm{NiFe}_{2} \mathrm{O}_{4} / \mathrm{MWCNTs}$ hybrids were prepared via one-step hydrothermal method at $180{ }^{\circ} \mathrm{C}$ for $20 \mathrm{~h}$, and their photocatalytic activity was investigated for the decolorization 
of Congo Red dye in aqueous solution under simulated solar light irradiation ${ }^{23}$. However, no work has yet been developed using $\mathrm{NiFe}_{2} \mathrm{O}_{4} / \mathrm{MWCNT}_{\mathrm{M}}$ composite prepared via microwave route for application as a photo-Fenton catalyst under visible light irradiation. It is well known that the use of microwave route for the preparation of powdered catalysts presents as great advantages short synthesis time and production of high surface area particles, being this last characteristic of great importance for catalytic purposes ${ }^{24,25}$.

$\mathrm{NiFe}_{2} \mathrm{O}_{4}$ is a cubic oxide with a typical inverse spinel structure and has attracted much interest because of its fascinating magnetic and electromagnetic properties ${ }^{26}$, while the MWCNTs have attracted increasing research interest as dye adsorbent ${ }^{27}$, support for enzyme immobilization ${ }^{28}$ and catalyst support ${ }^{29}$.

In this work, nickel ferrite $\left(\mathrm{NiFe}_{2} \mathrm{O}_{4}\right)$ /carbon nanotubes (MWCNTs) composite was prepared via a rapid alternative method (microwave route) for application as catalyst on degradation of amaranth dye using heterogeneous photo-Fenton process under visible light irradiation.

\section{Materials and Methods}

\subsection{Materials, procedures and characterization techniques}

Multi-walled carbon nanotubes (MWNTs-COOH functionalized) (Purity $>95 \mathrm{wt} \%$, outside diameter: 10-20 nm, inside diameter: 5-10 nm, Length: 10-30 mm) were purchased from Nanostructured \& Amorphous Materials, Inc., USA. Amaranth dye (CAS number: 915-67-3; chemical formula: $\mathrm{C}_{20} \mathrm{H}_{11} \mathrm{~N}_{2} \mathrm{Na}_{3} \mathrm{O}_{10} \mathrm{~S}_{3}$; molecular weight: $604.47 \mathrm{~g} \mathrm{~mol}^{-1}$ ) was used as a model pollutant. Nickel nitrate $\left[\mathrm{Ni}\left(\mathrm{NO}_{3}\right)_{2} \cdot 6 \mathrm{H}_{2} \mathrm{O}\right]$, iron nitrate $\left[\mathrm{Fe}\left(\mathrm{NO}_{3}\right)_{3} \cdot 9 \mathrm{H}_{2} \mathrm{O}\right]$ and anhydrous ethyl alcohol were utilized without any further treatment.

A modified procedure for the preparation of $\mathrm{NiFe}_{2} \mathrm{O}_{4} /$ MWCNTs composite was employed in this work, which was based on a previously reported work ${ }^{13}$, where a hydrothermal conventional method has been employed for the synthesis process $^{13}$. From hydrothermal route, $20 \mathrm{~h}$ of reaction time has been necessary for the production of the respective composite $^{13}$. Therefore, this present work aims to use microwave irradiation as heat source in order to accelerate the formation of material. For the obtaining the composite sample containing $25 \mathrm{wt} \%$ of MWCNTs, nickel nitrate (1.45 g) and iron nitrate $(4.04 \mathrm{~g})$ were firstly dissolved in $100 \mathrm{~mL}$ of ethyl alcohol. Then, $0.40 \mathrm{~g}$ of MWCNTs was dispersed in $600 \mathrm{~mL}$ of ethyl alcohol. After, the ethyl alcohol/MWCNTs suspension was added into the saline solution under stirring for $30 \mathrm{~min}$ at room temperature $\left(25^{\circ} \mathrm{C}\right)$. This suspension was adjusted to a $\mathrm{pH}$ value of 14 using $10 \mathrm{M} \mathrm{NaOH}$ solution, and kept under stirring for $15 \mathrm{~min}$. Then, $100 \mathrm{ml}$ of deionized water was added to previous suspension, and kept under vigorous stirring for $30 \mathrm{~min}$. Posteriorly, the final suspension was transferred to several high-pressure reaction vessels and submitted to microwave irradiation (MARS 6 Microwave equipment, ESP 1500 plus, USA), under the following conditions: temperature $\left(235^{\circ} \mathrm{C}\right)$, power $(500 \mathrm{~W})$, pressure (600 psi) and irradiation time ( $30 \mathrm{~min})$. The obtained composite was collected and washed with deionized water for several times, and then, dried at $110{ }^{\circ} \mathrm{C}$ for $12 \mathrm{~h}$. For comparison purposes of the catalytic activity, pure $\mathrm{NiFe}_{2} \mathrm{O}_{4}$ particles were prepared using the same previous mentioned procedure without the addition of MWCNTs. The concentration of free Fe ions in the solution after irradiation was measured by atomic absorption spectroscopy (Agilent Technologies, 200 series AA) to monitor their leaching from the catalysts.

Characterization of the materials was identified using an X-ray diffractometer (Rigaku Miniflex 300), with $\mathrm{Cu}-\mathrm{K} \alpha$ radiation, powered at $30 \mathrm{kV}$ and $10 \mathrm{~mA}$. Scans were performed over $2 \theta$ angles ranging from 15 to $65^{\circ}$. Thermogravimetric analysis was carried out on a TGA-50 Shimadzu analyzer at a heating rate of $10{ }^{\circ} \mathrm{C} \mathrm{min}^{-1}$ in presence of an air flow rate of $50 \mathrm{~mL} \mathrm{~min}^{-1}$, in the temperature range from 25 to $900{ }^{\circ} \mathrm{C}$. Nitrogen adsorption-desorption isotherms were obtained at $77 \mathrm{~K}$ carried out on an ASAP 2020 apparatus at relative pressure $\left(\mathrm{P} / \mathrm{P}_{0}\right)$ ranging from 0 to 0.99 . Specific surface areas were calculated according to the Brunauer-Emmett-Teller (BET) method and, the pore-size distributions were obtained according to the Barret-Joyner-Halenda (BJH) method. Raman spectroscopy measurements were performed at room temperature using a micro-positioning system B\&WTek and an Andor Shamrock 303 i monochromator. The morphology of the composite was examined by a scanning electron microscope (SEM, JEOL JSM-6610LV) at $15 \mathrm{kV}$, and its chemical composition was obtained by energy dispersive $\mathrm{X}$-ray spectroscopy (EDS), which is coupled to the SEM equipment.

\subsection{Photo-Fenton experiment}

For the degradation tests of $50 \mathrm{~mL}$ Amaranth dye solution at room temperature $\left(50 \mathrm{mg} \mathrm{L}^{-1}\right)$ and $\mathrm{pH} 2.5$ (adjusted using $\left.0.1 \mathrm{M} \mathrm{H}_{2} \mathrm{SO}_{4}\right)$, the catalyst amount $\left(\mathrm{NiFe}_{2} \mathrm{O}_{4}\right.$ and $\mathrm{NiFe}_{2} \mathrm{O}_{4} /$ MWCNTs composite) used was $0.05 \mathrm{~g}$ and the $\mathrm{H}_{2} \mathrm{O}_{2}(30 \%$ $\mathrm{v} / \mathrm{v}$ ) volume was $50 \mu \mathrm{L}$. Prior to illumination, the aqueous suspension containing catalyst and dye was magnetically stirred in the dark until to achieve the adsorption equilibrium. In order to avoid adherence of the magnetic catalyst on the magnetic bar, a vigorous agitation (150 rpm) was employed. It was found that an agitation rate above this value is adequate for to obtain a homogeneous suspension during the stirring step. Then the suspension was exposed to visible light irradiation under stirring. The visible-light source was commercial fluorescent lamp ( $85 \mathrm{~W}$, Empalux) positioned $10 \mathrm{~cm}$ above the liquid surface. Samples were taken at set intervals using a syringe and, filtered immediately through a PVDF membrane $(0.45 \mu \mathrm{m})$. The dye concentration in the filtered suspension was determined by the absorbance reading on an UV-vis spectrophotometer (Shimadzu, UV-2600), at a maximum absorption wavelength of $520 \mathrm{~nm}$. 


\section{Results and Discussion}

XRD diffraction patterns of MWCNTs, pure $\mathrm{NiFe}_{2} \mathrm{O}_{4}$ and $\mathrm{NiFe}_{2} \mathrm{O}_{4} / \mathrm{MWCNTs}$ composite are shown in Figure 1. The major peaks corresponding to the planes $\left(\begin{array}{lll}0 & 0 & 2\end{array}\right)$ and (1 $\left.\begin{array}{ll}1 & 1\end{array}\right)$ at $2 \theta$ positions of 26.5 and $43.4^{\circ}$ are characteristic peaks of MWCNTs ${ }^{30}$ (Figure 1a). In Figure 1b, the peaks located at $18.4,30.3,35.7,37.3,43.3,53.8,57.3$, and $63.0^{\circ}$ can be indexed to the (111), (220), (311), (222), (400), (422), (511) and (440) crystal planes of $\mathrm{NiFe}_{2} \mathrm{O}_{4}$ spinel, respectively, according to the JCPDS Card No. 54-0964 (Bars inset to Figure 1 correspond to reference $\mathrm{NiFe}_{2} \mathrm{O}_{4}$ ). From Figure 1c, the presence of the peak to $26.5^{\circ}$ (which corresponds to MWCNTs material) on the XRD pattern of the $\mathrm{NiFe}_{2} \mathrm{O}_{4} / \mathrm{MWCNTs}$ composite, indicates the successful formation of respective hybrid material.

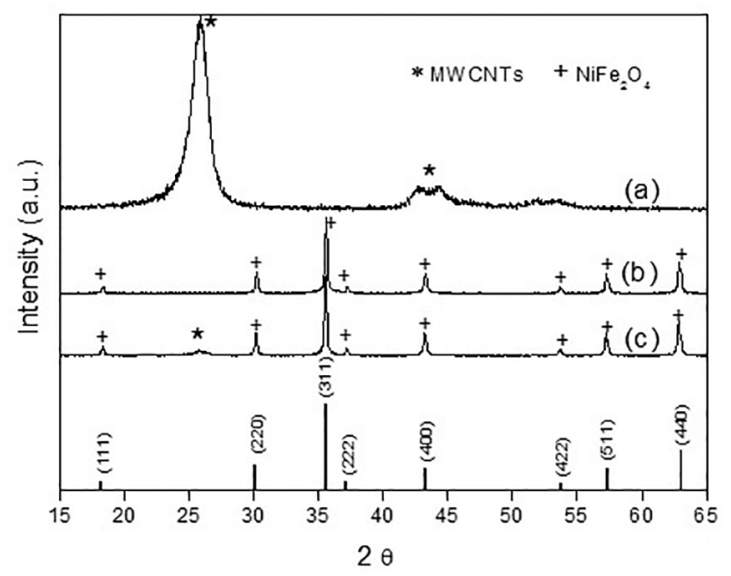

Figure 1. X-ray diffractograms of (a) MWCNTs, (b) pure $\mathrm{NiFe}_{2} \mathrm{O}_{4}$ and, (c) $\mathrm{NiFe}_{2} \mathrm{O}_{4} / \mathrm{MWCNTs}$ composite. Bars inset correspond to reference $\mathrm{NiFe}_{2} \mathrm{O}_{4}$, according to the JCPDS Card No. 54-0964.

Raman spectra of MWNTs, $\mathrm{NiFe}_{2} \mathrm{O}_{4} / \mathrm{MWNTs}$ composite and pure $\mathrm{NiFe}_{2} \mathrm{O}_{4}$ are shown in Figure 2. The peaks at $1350 \mathrm{~cm}^{-1}$ (band D) and $1580 \mathrm{~cm}^{-1}$ (band D) are typical of $\mathrm{MWCNTs}^{31}$ (Figure 2a), while the peaks to $470 \mathrm{~cm}^{-1}$ and $690 \mathrm{~cm}^{-1}$ correspond to typical peaks of $\mathrm{NiFe}_{2} \mathrm{O}_{4}{ }^{32}$ (Figure 2b). All peaks above mentioned are presents on the Raman spectrum of the $\mathrm{NiFe}_{2} \mathrm{O}_{4} / \mathrm{MWCNTs}$ composite (Figure 2c), demonstrating the successful preparation of the $\mathrm{NiFe}_{2} \mathrm{O}_{4} /$ MWNTs hybrid composite.

Thermogravimetric analysis (TGA) was used to evaluate the amount of MWCNTs incorporated on the prepared $\mathrm{NiFe}_{2} \mathrm{O}_{4} / \mathrm{MWCNTs}$ composite. Figure 3 shows the TGA of the pure $\mathrm{NiFe}_{2} \mathrm{O}_{4}$ (Figure 3a), $\mathrm{NiFe}_{2} \mathrm{O}_{4}$ /MWCNTs composite (Figure $3 b$ ) and MWCNTs (Figure 3c). According to Figure 3 , the MWCNTs have total mass loss at $800^{\circ} \mathrm{C}$ (Figure 3c), while the pure $\mathrm{NiFe}_{2} \mathrm{O}_{4}$ remains stable up to $900^{\circ} \mathrm{C}$ (Figure 3a). From Figure 3b, it is possible to observe a mass loss about $25 \%$, corresponding to thermal oxidation of MWNTs

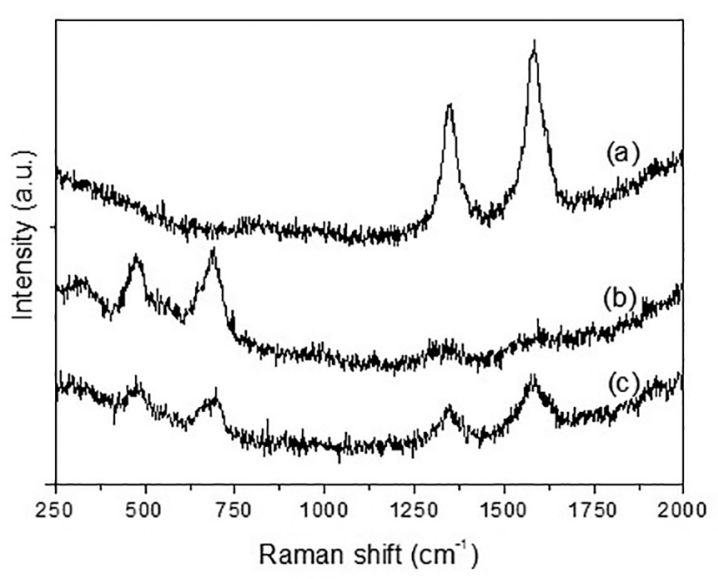

Figure 2. Raman spectra of (a) MWCNTs, (b) pure $\mathrm{NiFe}_{2} \mathrm{O}_{4}$ and, (c) $\mathrm{NiFe}_{2} \mathrm{O}_{4} / \mathrm{MWCNTs}$ composite.

presents in the $\mathrm{NiFe}_{2} \mathrm{O}_{4} /$ MWCNTs composite. This result indicates that the procedure used in this work for the composite preparation was done successfully.

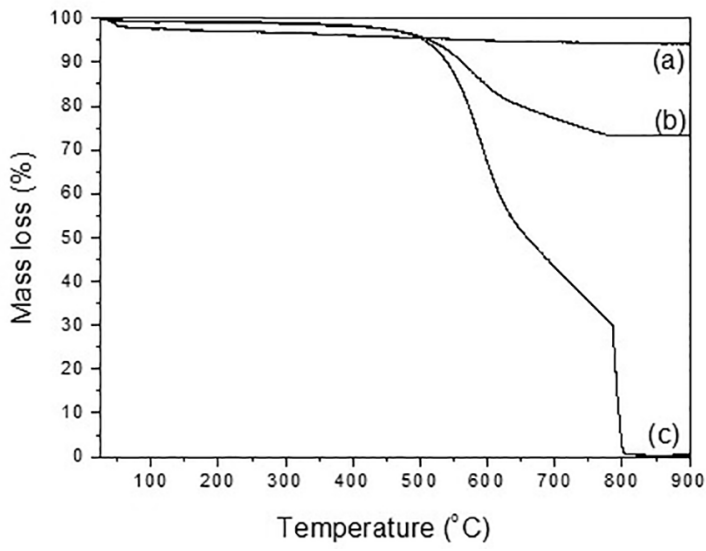

Figure 3. Thermogravimetric analysis of (a) pure $\mathrm{NiFe}_{2} \mathrm{O}_{4}$, (b) $\mathrm{NiFe}_{2} \mathrm{O}_{4}$ /MWCNTs composite, and (c) MWCNTs.

Representation of the nitrogen adsorption-desorption isotherms and pore-size distributions for MWCNTs, pure $\mathrm{NiFe}_{2} \mathrm{O}_{4}$ and $\mathrm{NiFe}_{2} \mathrm{O}_{4} /$ MWCNTs samples are shown in Figure 4 . The isotherms for the all the samples shown in Figure $4 \mathrm{a}$ are similar and can be classified as type II. The shape of these isotherms indicates that all the samples possess predominantly microporous structure. In addition, the microporous structure was confirmed by the analysis of pore-size distribution (Figure 4b), which shows spectra of pore-size distributed on the microporous region (pore-size less than $2 \mathrm{~nm}$ ). Pore properties of the samples are shown in Table 1. Values of surface area and total pore volume of $\mathrm{NiFe}_{2} \mathrm{O}_{4} /$ MWCNTs composite are between those of MWCNTs and pure $\mathrm{NiFe}_{2} \mathrm{O}_{4}$. 

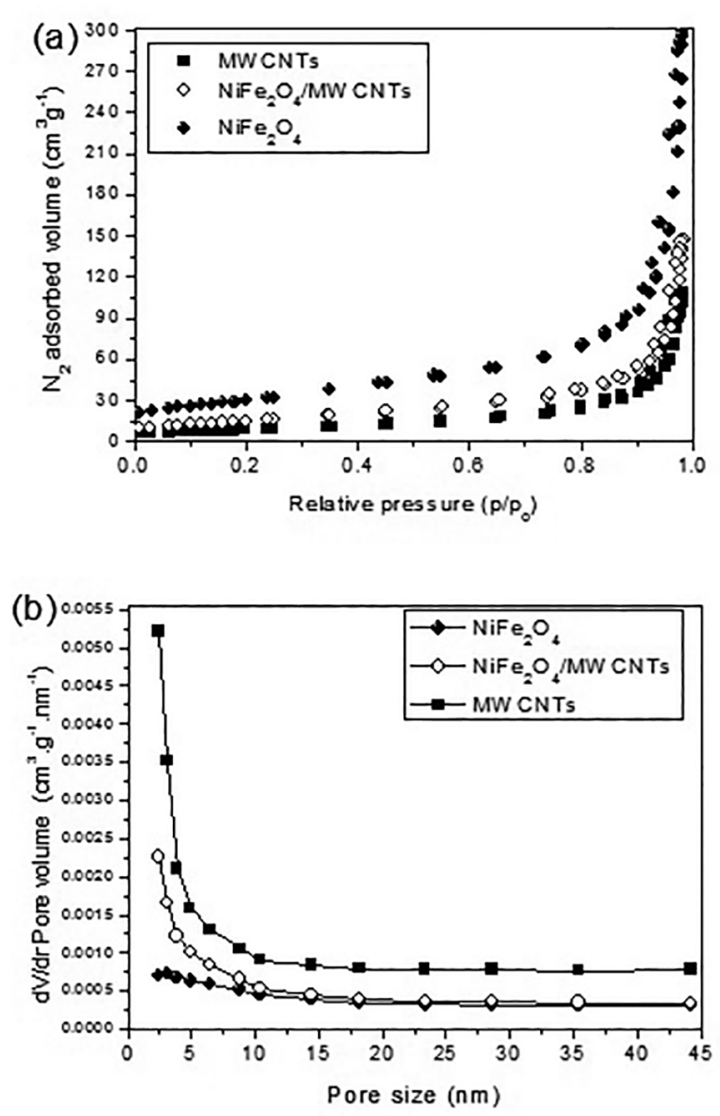

Figure 4. (a) Nitrogen adsorption/desorption isotherms of MWCNTs, $\mathrm{NiFe}_{2} \mathrm{O}_{4} / \mathrm{MWCNTs}$ and $\mathrm{NiFe}_{2} \mathrm{O}_{4}$ and, their (b) pore-size distributions.

Table 1. Pore properties of the samples.

\begin{tabular}{ccc}
\hline Sample & $\begin{array}{c}\text { Surface area } \\
\left(\mathbf{m}^{\mathbf{2}} \mathbf{g}^{-1}\right)\end{array}$ & $\begin{array}{c}\text { Total pore volume } \\
\left(\mathbf{c m}^{\mathbf{3}} \mathbf{g}^{-1}\right)\end{array}$ \\
\hline $\mathrm{NiFe}_{2} \mathrm{O}_{4}$ & 32 & 0.1684 \\
$\mathrm{MWCNTs}$ & 103 & 0.4881 \\
$\mathrm{NiFe}_{2} \mathrm{O}_{4} / \mathrm{MWCNTs}$ & 54 & 0.2249 \\
\hline
\end{tabular}

Figure 5 shows SEM images of $\mathrm{NiFe}_{2} \mathrm{O}_{4} / \mathrm{MWCNTs}$ composite (Figures (5a) and (5b) under different magnifications), $\mathrm{NiFe}_{2} \mathrm{O}_{4}$ (Figure (5c)) and MWCNTs (Figure (5d)). In Figure (5e), it is showed the chemical composition of composite obtained from EDS analysis. Particles with irregular shape can be observed on the respective images of the composite (Figure (5a)) and $\mathrm{NiFe}_{2} \mathrm{O}_{4}$ (Figure (5c)), whereas nanotubes well adhered on the surface of the $\mathrm{NiFe}_{2} \mathrm{O}_{4}$ particle can be observed in Figure (5b). In addition, it is possible to observe that the nanotubes maintained their morphology after the microwave process. From Figure (5e), it was found an atomic ratio of 1:2 (Ni:Fe), which confirms the formation of $\mathrm{NiFe}_{2} \mathrm{O}_{4}$ spinel.

Preliminary tests on the presence of catalyst in the dark without $\mathrm{H}_{2} \mathrm{O}_{2}$ (catalyst/dark), without catalyst $\left(\mathrm{H}_{2} \mathrm{O}_{2} /\right.$ light $)$
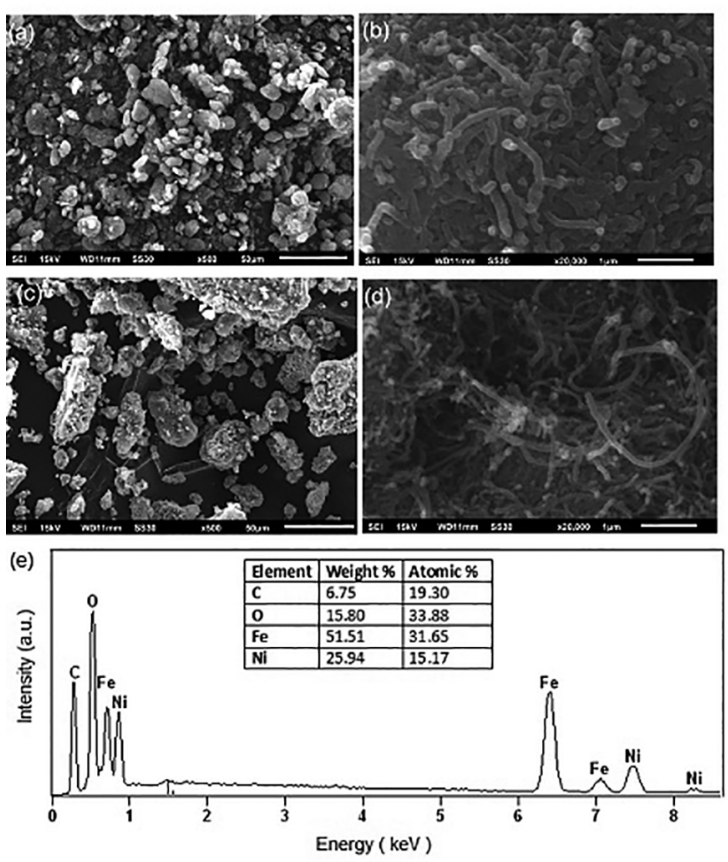

Figure 5. SEM images of $\mathrm{NiFe}_{2} \mathrm{O}_{4} / \mathrm{MWCNTs}$ composite [Magnification: $500 \mathrm{X}(\mathrm{a}) ; 20,000 \mathrm{X}$ (b)], $\mathrm{NiFe}_{2} \mathrm{O}_{4}$ (Magnification: $500 \mathrm{X}$ ) (c) and MWCNTs (Magnification: 20,000 X) (d), and EDS analysis (e) of $\mathrm{NiFe}_{2} \mathrm{O}_{4} / \mathrm{MWCNTs}$ composite.

and without $\mathrm{H}_{2} \mathrm{O}_{2}$ (catalyst/light) showed negligible decolorization results, whereas the Fenton process (catalyst/ $\mathrm{H}_{2} \mathrm{O}_{2} /$ dark) exhibited about $7.0 \%$ of decolorization at $60 \mathrm{~min}$ of reaction time. Therefore, the effective dye degradation is attributed to the synergetic effect of the combination among catalyst $/ \mathrm{H}_{2} \mathrm{O}_{2}$ /visible light (photo-Fenton process). As shown in Figure 6 , the linear relationship of $C / C_{0}$ versus reaction time shows that the dye decolorization via photo-Fenton process followed the zero-order kinetics ${ }^{3,8,33}$ for both the catalysts. The slopes of lines correspond to the reaction rate constants $\left(k_{\text {composite }}=0.017 \mathrm{mg} \mathrm{L}^{-1} \mathrm{~min}^{-1}\right.$ and $k_{\text {ferrite }}=$ $\left.0.001 \mathrm{mg} \mathrm{L}^{-1} \mathrm{~min}^{-1}\right)$. This result indicates that the composite shows higher activity compared to pure ferrite. The dye was substantially degraded from the aqueous solution, reaching $100 \%$ at $60 \mathrm{~min}$ of reaction time. On the other hand, $60 \%$ of decolorization was obtained at $60 \mathrm{~min}$ using pure ferrite. The significant enhancement in catalytic activity by the $\mathrm{NiFe}_{2} \mathrm{O}_{4} /$ MWCNTs composite can be attributed to the synergistic effect between $\mathrm{NiFe}_{2} \mathrm{O}_{4}$ and MWNTs that reduce the rate of recombination of photoinduced electrons and holes, leading to high catalytic performance ${ }^{13,30}$. In addition, the higher surface area and pore volume of $\mathrm{NiFe}_{2} \mathrm{O}_{4} / \mathrm{MWCNTs}$ composite compared to the pure $\mathrm{NiFe}_{2} \mathrm{O}_{4}$ could offer a larger contact and diffusion of dye molecules within the pores of its particles, contributing to the close contact between the $\mathrm{HO} \cdot$ radicals and dye molecules, which leads to an increasing reaction rate. 


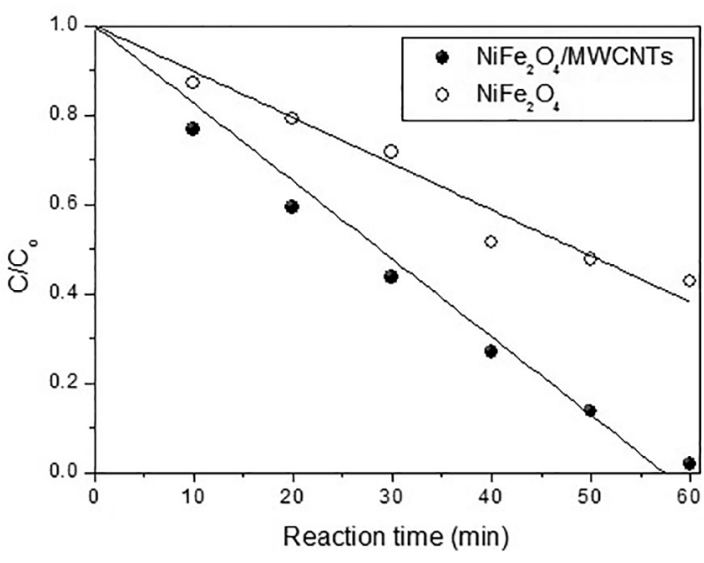

Figure 6. Catalytic activity of $\mathrm{NiFe}_{2} \mathrm{O}_{4}$ and $\mathrm{NiFe}_{2} \mathrm{O}_{4} / \mathrm{MWCNTs}$ for the degradation of Amaranth dye by photo-Fenton process.

From leaching essays for both the catalysts, very low amount of Fe (about $2 \mathrm{mg} \mathrm{L}^{-1}$ ) was detected by atomic absorption spectroscopy in the solution after $60 \mathrm{~min}$ of irradiation, indicating that the dye degradation was due to the heterogeneous Fenton reaction. According to Brazilian environmental legislation (CONAMA) ${ }^{34}$, a maximum of $15 \mathrm{mgFe} \mathrm{L}^{-1}$ is allowed for discharge into a body of water. Therefore, this result indicates a good stability of the catalyst in photo-Fenton reaction.

\section{Conclusions}

$\mathrm{NiFe}_{2} \mathrm{O}_{4} / \mathrm{MWCNTs}$ composite was successfully prepared using microwave irradiation technique. The studies showed the formation of single phase particles of $\mathrm{NiFe}_{2} \mathrm{O}_{4}$ on the composite. Hybrid material with surface area and total pore volume of $54 \mathrm{~m}^{2} \mathrm{~g}^{-1}$ and $0.2249 \mathrm{~cm}^{3} \mathrm{~g}^{-1}$, respectively, was obtained using a microwave irradiation time of $30 \mathrm{~min}$. $\mathrm{NiFe}_{2} \mathrm{O}_{4} / \mathrm{MWCNTs}$ composite was found to be a more efficient catalyst than the pure $\mathrm{NiFe}_{2} \mathrm{O}_{4}$ for the Amaranth degradation by the photo-Fenton reaction under visible light, reaching total degradation at $60 \mathrm{~min}$ of reaction time. Therefore, the combined effect between $\mathrm{NiFe}_{2} \mathrm{O}_{4}$ and MWNTs promoted a significant improvement in catalytic activity. The results indicated that the $\mathrm{NiFe}_{2} \mathrm{O}_{4} / \mathrm{MWCNT}$ composite could be employed as an efficient catalyst for the treatment of dye-containing wastewater.

\section{Acknowledgements}

The authors would like to thank to FAPERGS (Foundation for Research of the State of Rio Grande do Sul/Brazil) by the scholarship for the author C. R.

\section{References}

1. Ribeiro PC, Costa ACFM, Kiminami RHGA, Sasaki JM, Lira HL. Synthesis of $\mathrm{TiO}_{2}$ by the pechini method and photocatalytic degradation of methyl red. Materials Research. 2013;16(2):468-472. DOI: 10.1590/S1516-14392012005000176

2. Luna AJ, Nascimento CAO, Foletto EL, Moraes JEF, Chiavone-Filho O. Photo-Fenton degradation of phenol, 2,4-dichlorophenoxyacetic acid and 2,4-dichlorophenol mixture in saline solution using a falling-film solar reactor. Environmental Technology. 2014;35(3):364-371. DOI: 10.1080/09593330.2013.828762

3. Battiston S, Rigo, Severo EC, Mazutti MA, Kuhn RC, Gündel A, et al. Synthesis of zinc aluminate $\left(\mathrm{ZnAl}_{2} \mathrm{O}_{4}\right)$ spinel and its application as photocatalyst. Materials Research. 2014;17(3):734-738. DOI: 10.1590/S1516-14392014005000073

4. Kehinde F, Aziz HA. Textile waste water and the advanced oxidative treatment process, an overview. International Journal of Innovative Research in Science, Engineering and Technology. 2014;3(8):15310-15317. DOI: 10.15680/IJIRSET.2014.0308034

5. Filippo E, Carlucci C, Capodilupo AL, Perulli P, Conciauro F, Corrente GA, et al. Enhanced Photocatalytic Activity of Pure Anatase $\mathrm{TiO}_{2}$ and $\mathrm{Pt}-\mathrm{TiO}_{2}$ Nanoparticles Synthesized by Green Microwave Assisted Route. Materials Research. 2015;18(3):473-481. DOI: 10.1590/1516-1439.301914

6. Silva SS, Chiavone-Filho O, Barros Neto EL, Foletto EL. Oil removal from produced water by conjugation of flotation and photo-Fenton processes. Journal of Environmental Management. 2015;147:257-263. DOI: 10.1016/j.jenvman.2014.08.021

7. Baldissera MR, Silva MRA, Silveira CA, Lima RM, Maia SA, Silva MR, et al. Synthesis and characterization of $\mathrm{Zn}$ and $\mathrm{Mn}$ ferrites from spent batteries. Cerâmica. 2014;60(353):52-56. DOI: 10.1590/S0366-69132014000100007

8. Severo EC, Anchieta CG, Foletto VS, Kuhn RC, Collazzo GC, Mazutti MA et al. Degradation of Amaranth azo dye in water by heterogeneous photo-Fenton process using $\mathrm{FeWO}_{4}$ catalyst prepared by microwave irradiation. Water Science and Technology. 2016;73(1):88-94. DOI: 10.2166/wst.2015.469

9. Anchieta CG, Dotto GL, Mazutti MA, Kuhn RC, Collazzo GC, Chiavone-Filho O, et al. Statistical optimization of Reactive Red 141 removal by heterogeneous photo-Fenton reaction using $\mathrm{ZnFe}_{2} \mathrm{O}_{4}$ oxide prepared by microwave irradiation. Desalination and Water Treatment. 2016;57(33):15603-15611. DOI: $10.1080 / 19443994.2015 .1070761$

10. Pignatello JJ. Dark and photoassisted iron ${ }^{(3+)}$-catalyzed degradation of chlorophenoxy herbicides by hydrogen peroxide. Environmental Science and Technology. 1992;26(5):944-951. DOI: $10.1021 / \mathrm{es} 00029 \mathrm{a} 012$

11. Soon AN, Hameed BH. Degradation of Acid Blue 29 in visible light radiation using iron modified mesoporous silica as heterogeneous Photo-Fenton catalyst. Applied Catalysis A: General. 2013;450:96-105. DOI: 10.1016/j.apcata.2012.10.025 
12. Mota ALN, Chiavone-Filho O, Silva SS, Foletto EL, Moraes JEF, Nascimento CAO. Application of artificial neural network for modeling of phenol mineralization by photo-Fenton process using a multi-lamp reactor. Water Science and Technology. 2014;69(4):768-774. DOI: 10.2166/wst.2013.731

13. Xiong $\mathrm{P}$, Fu Y, Wang L, Wang X. Multi-walled carbon nanotubes supported nickel ferrite: A magnetically recyclable photocatalyst with high photocatalytic activity on degradation of phenols. Chemical Engineering Journal. 2012;195-196:149-157. DOI: 10.1016/j.cej.2012.05.007

14. Gabal MA, Al-Harthy EA, Angari YMA, Salam MA. MWCNTs decorated with $\mathrm{Mn}_{0.8} \mathrm{Zn}_{0.2} \mathrm{Fe}_{2} \mathrm{O}_{4}$ nanoparticles for removal of crystal-violet dye from aqueous solutions. Chemical Engineering Journal. 2014;255:156-164. DOI: 10.1016/j.cej.2014.06.019

15. Sun C, Liu Y, Ding W, Gou Y, Xu K, Xia G, et al. Synthesis and Characterization of Superparamagnetic $\mathrm{CoFe}_{2} \mathrm{O}_{4} / \mathrm{MWCNT}$ hybrids for Tumor-Targeted Therapy. Journal of Nanoscience and Nanotechnology. 2013;13(1):236-41. DOI: 10.1166/ jnn.2013.6711

16. Ensafi AA, Allafchian AR. Multiwall carbon nanotubes decorated with $\mathrm{NiFe}_{2} \mathrm{O}_{4}$ magnetic nanoparticles, a new catalyst for voltammetric determination of cefixime. Colloids and Surfaces B: Biointerfaces. 2013;102:687-693. DOI: 10.1016/j. colsurfb.2012.09.037

17. Farghali AA, Bahgat M, El Rouby WMA, Khedr MH. Decoration of MWCNTs with $\mathrm{CoFe}_{2} \mathrm{O}_{4}$ Nanoparticles for Methylene Blue Dye Adsorption. Journal of Solution Chemistry. 2012;41(12):2209-2225. DOI: 10.1007/s10953-012-9934-0

18. Wang W, Li Q, Chang C. Effect of MWCNTs content on the magnetic and wave absorbing properties of ferrite-MWCNTs composites. Synthetic Metals. 2011;161(1-2):44-50. DOI: 10.1016/j.synthmet.2010.10.032

19. Zhang Y, Zhu M, Zhang Q, Yu H, Li Y, Wang H. Solvothermal one-step synthesis of MWCNTs $/ \mathrm{Ni}_{0.5} \mathrm{Zn}_{0.5} \mathrm{Fe}_{2} \mathrm{O}_{4}$ magnetic composites. Journal of Magnetism and Magnetic Materials. 2010;322(14):2006-2009. DOI: 10.1016/j.jmmm.2010.01.023

20. Singh C, Bansal S, Singhal S. Synthesis of $\mathrm{Zn}_{1-\mathrm{x}} \mathrm{Co}_{\mathrm{x}} \mathrm{Fe}_{2} \mathrm{O}_{4} /$ MWCNTs nanocomposites using reverse micelle method: Investigation of their structural, magnetic, electrical, optical and photocatalytic properties. Physica B: Condensed Matter. 2014;444:70-76. DOI: 10.1016/j.physb.2014.03.033

21. Singhal S, Sharma R, Singh C, Bansal S. Enhanced Photocatalytic Degradation of Methylene Blue Using $\mathrm{ZnFe}_{2} \mathrm{O}_{4} / \mathrm{MWCNT}$ Composite Synthesized by Hydrothermal Method. Indian Journal of Materials Science. 2013;2013:356025. DOI: $10.1155 / 2013 / 356025$

22. Chen $\mathrm{CH}$, Liang $\mathrm{YH}$, Zhang WD. $\mathrm{ZnFe}_{2} \mathrm{O}_{4} / \mathrm{MWCNTs}$ composite with enhanced photocatalytic activity under visible-light irradiation. Journal of Alloys and Compounds. 2010;501(1):168-172. DOI: 10.1016/j.jallcom.2010.04.072
23. Zhu HY, Jiang R, Huang SH, Yao J, Fu FQ, Li JB. Novel magnetic $\mathrm{NiFe}_{2} \mathrm{O}_{4}$ /multi-walled carbon nanotubes hybrids: Facile synthesis, characterization, and application to the treatment of dyeing wastewater. Ceramics International. 2015;41(9 Pt B):11625-11631. DOI: 10.1016/j.ceramint.2015.05.122

24. Foletto EL, Simões JM, Mazutti MA, Jahn SL, Muller EI, Pereira LSF, et al. Application of $\mathrm{Zn}_{2} \mathrm{SnO}_{4}$ photocatalyst prepared by microwave-assisted hydrothermal route in the degradation of organic pollutant under sunlight. Ceramics International. 2013;39(4):4569-4574. DOI: 10.1016/j.ceramint.2012.11.053

25. Zawadzki M. Synthesis of nanosized and microporous zinc aluminate spinel by microwave assisted hydrothermal method (microwave-hydrothermal synthesis of $\mathrm{ZnAl}_{2} \mathrm{O}_{4}$ ). Solid State Sciences. 2006;8(1):14-18. DOI: $10.1016 / \mathrm{j}$. solidstatesciences.2005.08.006

26. Zabotto FL, Gualdi AJ, Eiras JA, Oliveira AJA, Garcia D. Influence of the Sintering Temperature on the Magnetic and Electric Properties of $\mathrm{NiFe}_{2} \mathrm{O}_{4}$ Ferrites. Materials Research. 2012;15(3):428-433. DOI: 10.1590/S1516-14392012005000043

27. Machado FM, Bergmann CP, Lima EC, Adebayo MA, Fagan SB. Adsorption of a Textile Dye from Aqueous Solutions by Carbon Nanotubes. Materials Research. 2014;17(Suppl. 1):153-160. DOI: 10.1590/S1516-14392013005000204

28. Garlet TB, Weber CT, Klaic R, Foletto EL, Jahn SL, Mazutti MA, et al. Carbon Nanotubes as Supports for Inulinase Immobilization. Molecules. 2014;19(9):14615-14624. DOI: 10.3390/molecules 190914615

29. Woan K, Pyrgiotakis G, Sigmund W. Photocatalytic Carbon Nanotube- $\mathrm{TiO}_{2}$ Composites. Advanced Materials. 2009;21(21):2233-2239. DOI: 10.1002/adma.200802738

30. Dalt SD, Alves AK, Bergmann CP. Photocatalytic degradation of methyl orange dye in water solutions in the presence of MWCNT/TiO 2 composites. Materials Research Bulletin. 2013;48(5):1845-1850. DOI: 10.1016/j.materresbull.2013.01.022

31. Nuernberg GB, Foletto EL, Probst LFD, Carreño NLV, Moreira MA. $\mathrm{MgAl}_{2} \mathrm{O}_{4}$ spinel particles prepared by metal-chitosan complexation route and used as catalyst support for direct decomposition of methane. Journal of Molecular Catalysis A: Chemical. 2013;370:22-27. DOI: 10.1016/j.molcata.2012.12.007

32. Jacob J, Khadar MA. Investigation of mixed spinel structure of nanostructured nickel ferrite. Journal of Applied Physics. 2010;107(11):114310-114319. DOI: 10.1063/1.3429202

33. Foletto EL, Battiston S, Simões JM, Bassaco MM, Pereira LSF, Flores EMM, et al. Synthesis of $\mathrm{ZnAl}_{2} \mathrm{O}_{4}$ nanoparticles by different routes and the effect of its pore size on the photocatalytic process. Microporous and Mesoporous Materials. 2012;163:2933. DOI: $10.1016 /$ j.micromeso.2012.06.039

34. CONAMA - National Council on Environment, Brazil. Available from: <http://www.mma.gov.br/port/conama>. Access in: 4/7/2017. 